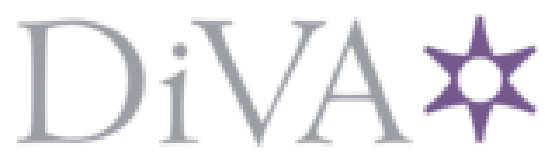

http://www.diva-portal.org

\title{
Postprint
}

This is the accepted version of a paper published in Fuel processing technology. This paper has been peer-reviewed but does not include the final publisher proof-corrections or journal pagination.

Citation for the original published paper (version of record):

Weiland, F., Nordwaeger, M., Olofsson, I., Wiinikka, H., Nordin, A. (2014)

Entrained flow gasification of torrefied wood residues.

Fuel processing technology, 125: 51-58

http://dx.doi.org/10.1016/j.fuproc.2014.03.026

Access to the published version may require subscription.

N.B. When citing this work, cite the original published paper.

Permanent link to this version:

http://urn.kb.se/resolve?urn=urn:nbn:se:umu:diva-91248 


\section{Entrained flow gasification of torrefied wood residues}

2 Fredrik Weiland $^{\mathrm{a}, \mathrm{b}^{*}}$, Martin Nordwaeger ${ }^{\mathrm{c}}$, Ingemar Olofsson ${ }^{\mathrm{c}}$, Henrik Wiinikka ${ }^{\mathrm{a}, \mathrm{b}}$ and

3 Anders Nordin ${ }^{\mathrm{c}}$,

$4 \quad{ }^{a}$ Energy Technology Centre, Box 726, SE-94128 Piteå, Sweden

5 b Division of Energy Science, Luleå University of Technology, SE-97187 Luleå,

6 Sweden

$7 \quad{ }^{\mathrm{c}}$ Energy Technology and Thermal Process Chemistry Group, Umeå University, SE-

890187 Umeå, Sweden

9 * Corresponding Author. Present address: Box 726, SE-941 28 Piteå, Sweden.

10 Tel: +46 911 232009. E-mail address: fredrik.weiland@etcpitea.se

\section{Abstract}

12 In this work, four different fuels were gasified in a pressurized entrained flow pilot plant

13 gasifier at approximately $270 \mathrm{~kW}_{\text {th. }}$. The different fuels were; two torrefied wood

14 residues, one raw wood residue and one torrefied stem wood. The system pressure and

15 oxygen equivalence ratio $(\lambda)$ were held constant for all four gasification experiments. It

16 was found that the torrefaction pretreatment significantly reduced the milling energy

17 consumption for fuel size reduction, which in turn contributed to increased gasification

18 plant efficiency. Furthermore, the results indicate that the carbon conversion efficiency

19 may be enhanced by an intermediate torrefaction pretreatment, whereas both less- and

20 more severe torrefaction resulted in reduced carbon conversions. The results also

21 indicate that the $\mathrm{CH}_{4}$ yield was significantly reduced for the most severely torrefied

22 fuel. 


\section{$1 \quad$ Highlights}

2

3

4

5

\section{Keywords}

7 Entrained-flow gasification, Biomass, Torrefaction, Wood, Syngas, Methane

\section{Introduction}

9 Large-scale, pressurized entrained flow gasification (PEFG) of fossil coal has proven

10 industrially preferable in terms of cost-efficiently producing a clean product gas,

11 essentially free from products of incomplete gasification such as char, soot, tars and

12 other lower molecular weight hydrocarbons (e.g. $\mathrm{CH}_{4}, \mathrm{C}_{2} \mathrm{H}_{2}$ ) [1]. This high conversion

13 efficiency as well as the inherent fuel flexibility are two major advantages of the PEFG-

14 process. There are enough coal based installations around the world, 96 (2010),

15 demonstrating the economic viability of the PEFG process [2]. Global coal based

16 installations are consequently continuously increasing with the majority of the present

17 PEFG projects generally aimed for either power production, petrochemicals or liquid

18 fuels production in China and US [2].

19 A number of studies have also identified PEFG as one of the most promising technologies for large-scale biomass conversion to higher-value energy carriers, liquid

21 fuels and petrochemicals, e.g. [3-5]. Quite few practical PEFG test campaigns have

22 however so far been performed for biomass raw materials at pilot- or commercial scale.

23 Pilot scale PEFG experiments with solid biomass is to our knowledge limited to the 
1 studies performed by Weiland et.al, where gasification of stem wood and bark mixtures

2 were gasified at approximately $200 \mathrm{~kW}$ scale [6, 7]. In addition to this, Wolters et al.

3 and Padban described occasional trials of co-firing coal and biomass in a $250 \mathrm{MW}_{\mathrm{e}}$

4 IGCC plant in Buggenum [8, 9]. In the study of Padban, torrefied biomass corresponded

5 to approximately $70 \%$ of the fuel mixture on energy basis. One reason for this limited

6 experience is that biomass powder is generally considered difficult and problematic in

7 terms of feeding $[10,11]$ and ash behavior $[5,12]$.

8 Compared to fossil coal powder, the use of powder from traditional biomass materials

9 may result in increased tar formation and methane production due to lower flame temperature primarily because of the lower heating value of the biomass. Furthermore,

11 production of powder from traditional biomass often needs expensive equipment

12 adoptions or reconstruction of existing coal handling and powder production equipment.

13 Some kind of biomass pretreatment would therefore be desirable to facilitate the use of

14 commercially available, lower cost and proven handling equipment either in the coal

15 PEFG-train with no or minor adaptations, or in new biomass based installations.

16 Torrefaction has been identified as such a (promising) thermal pretreatment method to

17 potentially facilitate large-scale cost-efficient PEFG of biomass. By exposing the

18 biomass to temperatures in the region of $230-350^{\circ} \mathrm{C}$ during 1 to 60 minutes, a number of

19 critical material properties are significantly improved to the benefit of subsequent

20 conversion [13]. During the process, biomass is degraded and volatiles are released as

21 torrefaction gas, decreasing the oxygen content and increasing the carbon content of the

22 biomass material. These changes also improve the heating value and friability (i.e. also

23 powder size distribution after milling) of the biomass material, and thus potentially

24 influencing both gasification process chemistry and the efficiencies of the process. 
1 Furthermore, the fuel particles may become more spherical, making it more easily to

2 feed in pneumatic systems.

3 Because of the generally improved characteristics of torrefied and compacted biomass

4 materials, the whole supply chain of raw material handling, storage and transportation is

5 significantly improved; costs and carbon footprints are reduced as exemplified by for

6 example Uslu et al. and Svanberg et al. [14, 15]. Comparing different pretreatment

7 methods and supply systems for biomass feeding of large-scale PEFG plants it has been

8 concluded that a feedstock based on torrefied materials to be the preferable route for

9 introducing biomass to PEFG systems already developed and available for coal [3, 16,

10 17]. Another important aspect in favor for biomass pretreatment by torrefaction is the

11 significant variations in market conditions and thereby economy of a large-scale

12 gasification plant as a result of varying feedstock, $\mathrm{CO}_{2}$ credit and electricity prices.

13 Meerman et al. stressed the importance of flexible feedstock operation, i.e. industrial

14 systems facilitating straightforward switching between coal and torrefied biomass,

15 depending on varying economic and raw material prerequisites [18-20]. A green coal in

16 the form of torrefied biomass materials would facilitate this flexibility since the existing

17 coal feeding system can be used for the torrefied materials while traditional biomass

18 requires a dedicated fuel feeding system [19].

19 The changes imposed on the biomass during torrefaction may however also result in

20 reduced performance in the PEFG process as volatile matter is decreased and reactivity

21 changed. The process chemistry and behavior of the fuel particles are significantly

22 influenced by the volatile content, particle size distribution and morphology, where the

23 reduced volatile content could decrease reactivity but the smaller particle sizes instead

24 increase the conversion rate during gasification. It should however be stated that the

25 higher reactivity of biomass may in fact allow less requirements on size reduction than 
1 what is experienced with coal and also facilitating sufficiently high gasification

2 efficiency at a somewhat lower temperature.

3 In the work by Couhert et al. [21], atmospheric steam gasification of beech wood and

4 torrefied beech wood was studied in a lab-scale drop-tube furnace at $1200^{\circ} \mathrm{C}$ and

$51400^{\circ} \mathrm{C}$. It was found that the amounts of residual carbon (char that was not gasified by

6 steam) were higher for the torrefied wood fuels compared to the original beech wood at

$71200^{\circ} \mathrm{C}$. This indicates a reduction in fuel conversion efficiency for the torrefied fuels

8 by gasification with steam. However, Chen et al. [22] found that the torrefaction

9 temperature affected the cold gas efficiency (CGE) of their experiments with sawdust

10 performed at $1200^{\circ} \mathrm{C}$ in a drop-tube furnace using $\mathrm{O}_{2}$ as the gasification agent. They

11 found an optimum in CGE (i.e. also fuel conversion) at a torrefaction temperature of

12 approximately $250^{\circ} \mathrm{C}$, whereas both less- and more severe torrefaction pretreatment

13 resulted in lower CGE. This result was attributed to the measured pore structure of the

14 fuels, where the sawdust torrefied at $250^{\circ} \mathrm{C}$ had the largest specific area and smallest

15 pore size.

16 Based on the experimental results from the drop-tube experiments described above, [21,

1722 ], there is an indication that severely torrefied fuels may result in reduced carbon

18 conversion efficiency from gasification. However, the drop-tube results were both

19 obtained with controlled fuel particle size distributions (by sieving) under allothermal

20 conditions at fixed gasification temperatures in lab-scale $(<2 \mathrm{~kW})$. In the present work

21 we compare the operation of an autothermal pressurized entrained flow pilot-scale

22 gasifier (approximately $270 \mathrm{~kW}$ ) using a reference wood powder and different torrefied

23 materials. The primary objective was to (1) study the effect of torrefaction on the fuel

24 carbon conversion efficiency and (2) study how the syngas content of $\mathrm{CH}_{4}$ is affected

25 by the torrefaction pretreatment. This is an important factor if the syngas is intended for 
1 catalytic conversion to synthetic motor fuels, or chemicals, since the $\mathrm{CH}_{4}$ often is inert

2 through the synthesis plant and therefore only accounts as losses.

3 The secondary, more general, objectives of the present work was to; (3) evaluate the

4 feasibility of feeding and operating the gasifier on torrefied biomass powder and (4)

5 evaluate if the torrefaction would significantly change gasification plant performance.

\section{$6 \quad 2 \quad$ Materials and Methods}

\section{$7 \quad 2.1 \quad$ General description of the pilot plant}

8 The Pressurized Entrained flow Biomass Gasification (PEBG) pilot plant, situated at

9 Energy Technology Centre (ETC) in Piteå, Sweden, was designed to operate in slagging

10 mode with process temperatures ranging between $1200-1500^{\circ} \mathrm{C}$. The pilot plant is

11 described in detail by Weiland et al. [6] and therefore only a brief description is given

12 here. A schematic process flow diagram is shown in Figure 1. The PEBG gasifier

13 consist of a ceramic lined reactor followed by a bubbling 2-level water sprayed quench

14 for syngas cooling and smelt/particle separation. The process temperature inside the

15 reactor is measured by five thermocouples at different locations inside the reactor,

16 placed with the tip coincident with the inner reactor wall. One thermocouple was placed

17 at the top part of the reactor, three thermocouples in the middle part of the reactor

18 equally separated by $120^{\circ}$ and one thermocouple in the bottom part of the reactor.

19 The fuel powders were prepared by milling the considered fuel materials in a hammer mill. After milling, the fuel powders were pneumatically transported to two fuel hoppers

21 in the feeding system located above the reactor in the PEBG plant. The two hoppers are

22 operated alternately in order to sustain the process operating pressure. After

23 pressurization of the fuel hoppers, the fuel was transported by the fuel feeding system

24 and introduced in the top of the reactor. The supplied amount of $\mathrm{O}_{2}$ used in the 
1 gasification process was controlled by a mass flow controller (MFC) and introduced in

2 the top of the reactor via an $\mathrm{O}_{2}$ register located concentrically outside the fuel entrance

3 of the burner. Moreover, the $\mathrm{O}_{2}$ concentration in the burner $\mathrm{O}_{2}$ register could be altered

4 by introducing $\mathrm{N}_{2}$ (via a $\mathrm{N}_{2}$ MFC) into the $\mathrm{O}_{2}$ flow. An $\mathrm{O}_{2}$ concentration of

5 approximately 90 mol\% was used in the burner $\mathrm{O}_{2}$ register for the campaigns described

6 in this work.

7 A vertically installed electrical heater was used to heat up the reactor ceramics to

8 approximately $1000^{\circ} \mathrm{C}$ prior to process start-up. After removing the electrical heater, the

9 powder burner was installed and the gasification process was started at atmospheric

10 pressure by feeding the fuel powder and $\mathrm{O}_{2}$ to the reactor. Pressurization of the plant

11 was then accomplished by gradually closing the pressure control valve on the syngas

12 outlet until the desired pressure was reached. A general start-up procedure was to

13 operate the gasification process at a high oxygen equivalence ratio $(\lambda)$ in order to

14 quickly reach a process temperature above $1200^{\circ} \mathrm{C}$. Here $\lambda$ was defined as the ratio

15 between the supplied $\mathrm{O}_{2}$ and the $\mathrm{O}_{2}$ addition at stoichiometric combustion. After

16 reaching approximately $1200^{\circ} \mathrm{C}$, the process conditions were adjusted according to plan.

17 In the case of process shut down, the reactor was purged with $\mathrm{N}_{2}$ to evacuate all product

18 gases before the process was restarted.

19 The water sprays in the quench (Figure 1) cooled the raw syngas and other products

20 from the reactor (i.e. gases, particulates and ash/char) to temperatures below $100^{\circ} \mathrm{C}$.

21 Separated particles in the quench (i.e. ash or possible char and soot particles) either

22 settled at the bottom of the quench or in the sedimentation vessel downstream the

23 quench water outlet. The process pressure was controlled by a pressure control valve on

24 the syngas outlet pipe (see Figure 1). A slip stream of the pressure relieved and cool

25 syngas could be sampled from the outlet syngas pipe. The produced syngas flow was 
1 flared on top of the building. A $\mathrm{N}_{2}$ purged and water cooled camera probe was installed

2 in the top of the reactor. The camera was a valuable tool for the operators to

3 qualitatively analyze the gasification flame during operation. For safe process control

4 and automation, a PLC (Programmable Logic Controller) based control system was

5 used, and relevant process values were stored in a database for post processing of the

6 results from the experiments.

\section{$7 \quad 2.2$ Biomass feedstocks and preparation}

8 Four different fuels were gasified in this work; one raw wood residue (Raw); two

9 torrefied wood residues (Torr-300 and Torr-340) and one torrefied stem wood (Torr-

10 demo). The Raw fuel had a slightly different composition compared to the original

11 biomass of the Torr-300 and Torr-340 fuels. The Raw biomass consisted of wood

12 residue chips of $45 \%$ hardwood (birch) and 55\% softwood (pine), whereas the biomass

13 feed for production of Torr-300 and Torr-340 were wood residue chips consisting of

$1445 \%$ hardwood (birch) and 55\% softwood (whereof 35\% pine and $20 \%$ spruce),

15 according to Table 1 . The Torr-300 and Torr-340 were torrefied in a continuous

16 torrefaction pilot plant, where the residence time in the torrefaction reactor was set to

174.5 minutes and the final torrefaction biomass surface temperatures were $300^{\circ} \mathrm{C}$ and

$18340^{\circ} \mathrm{C}$ respectively. Biomass feed for Torr-demo was a mixture of stem wood chips of

19 Pine and Norway Spruce. Torrefaction of Torr-demo was performed in a continuous

20 torrefaction demo plant located in Klintehamn, Gotland, Sweden, with a maximum

21 capacity of $1 t_{\mathrm{DS}} / \mathrm{h}$ utilizing an indirectly flue gas heated rotary drum. The residence

22 time in the reactor was approximately $45-60$ minutes at a temperature of $245^{\circ} \mathrm{C}$. The

23 wood residues (Raw, Torr-300 and Torr-340) were in the form of chips when fed to the

24 powder mill, whereas the Torr-demo was in the form of pellets. Moisture content of the

25 powders prior to gasification was between 2 and $3 \%$. 
1 Torrefaction settings and fuel properties of the torrefied and the raw samples are

2 presented in Table 1 . The $\mathrm{C}, \mathrm{H}$ and $\mathrm{O}$ composition of the Raw fuel was very close to the

3 stem wood reference fuel described earlier by [6]. The $\mathrm{C}, \mathrm{H}$ and $\mathrm{O}$ composition of the

4 Torr-340 fuel showed similarities with some brown coal reference fuels described in

5 existing literature $[1,23]$, whereas the Torr-300 and Torr-demo fuels were milder

6 torrefied and approaching similar C, $\mathrm{H}$ and $\mathrm{O}$ compositions as peat [24].

7 The four fuels considered in this work were milled to powders using a granulator (Rapid

8 Granulator 15 Series) and a hammermill (MAFA EU-4B) connected in series. The

9 granulator sieve size was $5 \mathrm{~mm}$, whereas the sieve size in the hammermill was $0.75 \mathrm{~mm}$

10 for all fuels. The milling power consumption was continuously logged in order to

11 calculate the milling energy consumption for each fuel. The hammermill power

12 consumption was measured and logged to the database with a CarloGavazzi WM22-

13 DIN Power Analyser instrument, whereas the power consumption of the granulator was

14 measured with a tong ammeter.

15 Representative samples from each fuel powder were studied in a light microscope

16 (Zeiss Stemi 2000-C equipped with a digital camera for imaging).

\section{$17 \quad 2.3 \quad$ Gasification experiments}

18 The aim was to evaluate the four different fuels at similar operating conditions in the

19 gasification process. In this work, it was decided to keep the thermal power, the system

20 pressure and the oxygen equivalence ratio $(\lambda)$ constant for the four campaigns. In Table

212 the main experimental settings for the performed gasification experiments are

22 presented. 


\section{$1 \quad$ 2.3.1 Gas sampling}

2 Syngas sampling was performed by letting a small slip stream of the produced syngas

3 flow from the outlet syngas pipe (after the pressure control valve) through a particulate

4 removal equipment and a water cooled condenser. The dried syngas was then analyzed

5 consecutively by a micro-GC (Micro Gas Chromatograph Varian 490 GC with

6 Molecular sieve 5A and PoraPlot U columns equipped with two thermal conductivity

7 detectors, TCD).

\section{$8 \quad$ 2.3.2 Mass and energy balances - Definitions}

9 The total syngas flow was not measured directly. Instead, $\mathrm{N}_{2}$ was used as a tracer

10 making it possible to calculate the total mass flow of dry syngas from the $\mathrm{N}_{2}$

11 concentration in the syngas. This is possible under the assumption that all the trace gas

12 is inert and the added amount of $\mathrm{N}_{2}$ ends up in the syngas, without transforming into

13 other compounds.

14 The carbon conversion was calculated as the ratio of carbon atoms in the syngas $(\mathrm{mol} / \mathrm{s})$

15 over the amount of input carbon atoms from the corresponding fuel (mol/s) as

16 previously described by Weiland et al. [6]. This is however different from the general

17 definition of carbon conversion, where the definition is based on the difference between

18 input carbon atoms from the fuel and the output carbon atoms in the gasification residue

19 [1]. There is a potential difference between the carbon conversions calculated with these

20 two different definitions, where the former definition (used in this work) being the most

21 conservative.

22 The lower heating value (LHV) of the syngas was calculated as the sum of each

23 components contribution to the heating value according to:

$24 \quad L H V_{\text {syngas }}=\frac{1}{100} \cdot \sum_{i} c_{i} \cdot L H V_{i}$, 
1 where the components $i$ were $\mathrm{H}_{2}, \mathrm{CO}, \mathrm{CH}_{4}, \mathrm{C}_{2} \mathrm{H}_{4}$ and $\mathrm{C}_{2} \mathrm{H}_{2}$.

2 The Cold Gas Efficiency (CGE) was defined as the ratio between the energy in the

3 produced cooled syngas and the energy input from the corresponding fuel according to:

$4 \quad C G E=\frac{\dot{m}_{\text {syngas }} \cdot L H V_{\text {syngas }}}{\dot{m}_{\text {fuel }} \cdot L H V_{\text {fuel }}}$

5 where the subscripted $\dot{\mathrm{m}}$ represents the mass flow $(\mathrm{kg} / \mathrm{s})$ of fuel and syngas,

6 respectively. LHV represents the lower heating value $(\mathrm{MJ} / \mathrm{kg})$ for fuel and syngas

7 (subscripted), respectively. Two different Cold Gas Efficiencies (CGE's) were

8 calculated for the process: $\mathrm{CGE}_{\text {power }}$ was based on $\mathrm{LHV}_{\text {syngas }}$ using all the combustible

9 gas species in the calculation. $\mathrm{CGE}_{\text {fuel }}$ was based on $\mathrm{LHV}_{\text {syngas }}$ using only $\mathrm{CO}$ and $\mathrm{H}_{2}$

10 concentrations in the calculation. The $\mathrm{CGE}_{\text {power }}$ is a representative measure for the

11 gasification efficiency if the syngas is intended for power production, whereas $\mathrm{CGE}_{\text {fuel }}$

12 is considered as a better measure if the syngas is intended for synthetic fuel production,

13 where $\mathrm{CO}$ and $\mathrm{H}_{2}$ are the only important gas species.

14 Power consumption for fuel size reduction can be significant for entrained flow biomass

15 gasification processes. The total plant efficiency, $\eta_{\text {plant }}$, taking the power consumption

16 for milling into account, is of great importance for commercial applications. The

17 electrical power used for milling can be generated in e.g. a gas turbine or gas engine

18 from the syngas produced in the plant. However, the electrical efficiencies, $\eta_{\mathrm{el}}$, for gas

19 turbines or gas engines are currently approximately $0.3-0.4$ [25]. In this work the plant

20 efficiency, $\eta_{\text {plant}}$, was defined as:

$21 \quad \eta_{\text {plant }}=\frac{\dot{m}_{\text {syngas }} \cdot L H V_{\text {syngas }}-\frac{w_{\text {milling }}}{\eta_{\text {el }}} \cdot \dot{m}_{\text {fuel }}}{\dot{m}_{\text {fuel }} \cdot{ }^{L} V_{\text {fuel }}}$, 
1 where the subscripted $\dot{\mathrm{m}}$ and LHV represents the mass flow $(\mathrm{kg} / \mathrm{s})$ and LHV $(\mathrm{MJ} / \mathrm{kg})$ of

2 fuel and syngas, respectively. The prime electrical power consumption for milling,

$3 \mathrm{~W}_{\text {milling }}\left(\mathrm{MJ} / \mathrm{kg}_{\text {fuel }}\right)$, is here compensated for the electrical efficiency, $\eta_{\mathrm{el}}=0.40$, of a gas

4 turbine or a gas engine.

\section{$5 \quad 3 \quad$ Results and discussion}

\section{$6 \quad 3.1 \quad$ Milling and fuel powders}

7 The milling energy consumptions for the considered fuels are presented in Table 3 . The

8 Raw (un-torrefied) fuel required almost $36 \mathrm{kWh}$ electricity per $\mathrm{MWh}_{\mathrm{th}}$ of fuel (based on

9 LHV), whereas the three torrefied fuels all required less than $10 \mathrm{kWh}_{\mathrm{el}} / \mathrm{MWh}_{\mathrm{th}}$. The 10 torrefied chips (Torr-300 and Torr-340) were brittle and required less force for breaking

11 the chips perpendicular to the fiber direction compared to the Raw fuel. As mentioned

12 earlier, the Torr-demo was delivered as pellets and therefore additionally pretreated

13 compared to the other fuels. The pelletization process may explain why the Torr-demo

14 fuel had the lowest milling energy.

15 In Figure 2, magnified pictures of the resulting powders are shown. The Raw fuel photo

16 (A) show that the particles consist of elongated bundles of fibers. These particles are

17 relatively large and there were also less fine particles in the Raw powder sample

18 compared to the other three fuel samples. The fibrous particle structure can also be seen

19 for Torr-300 (B) and Torr-demo (D). However, the most severely torrefied fuel, Torr-

20340 powder (C), had explicitly different particles compared to the other fuels. The

21 fraction of fine particles was significantly larger than for the other fuels with essentially

22 no large fiber bundles. This indicates that the particle size reduction efficiency increases 23 with the degree of torrefaction. 


\subsection{Gasification experiments}

\section{$2 \quad 3.2 .1$ Temperature and operation performance}

3 The gasification experiments in this work were designed to fit within one working day

4 for each fuel and the prepared amount of fuel powder was therefore limited by this

5 restriction. The prepared fuel powders were either transported to hopper 1, hopper 2 or

6 both for practical reasons or depending on the powder bulk density. In Figure 3 to

$7 \quad$ Figure 6 the measured dry and $\mathrm{N}_{2}$ free syngas compositions (mol\% $\mathrm{CO}, \mathrm{H}_{2}, \mathrm{CO}_{2}$ and

$\left.8 \mathrm{CH}_{4}\right)$ are presented together with the process temperature profiles for the four different

9 gasification experiments. The average process temperature given by the three

10 thermocouples at different azimuthal position at mid height in the reactor is hereafter

11 referred to unless specified otherwise. All sharp temperature drops in the graphs are due

12 to the cooling effect of the $\mathrm{N}_{2}$ purge whenever the process was shut down. The Torr-300

13 fuel was the most voluminous fuel powder, Table 3. Therefore, it had to be filled in both

14 hoppers in order to hold the required amount of fuel for the experiment. The gasification

15 experiment started with feeding from hopper 1 (Figure 4), which gave relatively smooth

16 temperature and gas concentration profiles. However, after a minor process interruption,

17 the process was restarted from hopper 2, which resulted in much more irregular

18 temperature and gas concentration profiles because of the unsteady fuel feeding from

19 this hopper. Similar irregularities in the temperature profile can be noted for the Torr-

20 demo experiment (Figure 6), which also was fed from hopper 2. However, even though

21 there was an irregular fuel feeding, the variation of the syngas components $\mathrm{CO}, \mathrm{H}_{2}$ and

$22 \mathrm{CO}_{2}$ were within approximately $\pm 1 \mathrm{~mol} \%$ in the Torr-demo case. The reason for the

23 less consistent fuel feeding from hopper 2 is known and the plant was reconstructed

24 after the experiments described in this work to avoid future problems. 


\section{$1 \quad 3.2 .2 \quad$ Gasification process analysis}

2 The accumulated runtimes and final process temperatures were different for the four

3 experiments, i.e. none of the experiments reached thermal equilibrium, partly because

4 the limited amount of fuel. In order to better compare the different fuels during these

5 transient conditions, a temperature range of $1210^{\circ} \mathrm{C}-1250^{\circ} \mathrm{C}$ was chosen for

6 comparison. This temperature increase, $1210^{\circ} \mathrm{C}-1250^{\circ} \mathrm{C}$, required different amount of

7 time for the different fuels. It took approximately $34 \mathrm{~min}, 44 \mathrm{~min}, 57 \mathrm{~min}$ and $78 \mathrm{~min}$

8 for Torr-340, Torr-300, Raw and Torr-demo, respectively. These differences in

9 temperature increase rates may have several reasons. It may be explained by differences

10 in flame structure and heat transfer processes during gasification. This needs, however,

11 to be further investigated.

12 As expected, the syngas generated from the Raw fuel was relatively similar to the

13 syngas from stem wood previously described by Weiland et al. [6]. In Table 4, the

14 average main gas compositions (dry and $\mathrm{N}_{2}$ free) for the temperature range $1210-$

$151250^{\circ} \mathrm{C}$ are presented for the four fuels.

16 Compared to the results from gasifying the Raw fuel at the same temperature and

17 equivalence ratio, the severity of torrefaction clearly affected the compositions of $\mathrm{CO}$,

$18 \mathrm{CO}_{2}$ and $\mathrm{CH}_{4}$, whereas there was no such obvious effect for $\mathrm{H}_{2}$. However, the change in

19 syngas composition may be an effect of the totally lower amount of available oxygen in

20 the gasification process for the torrefied fuels as an artifact of the definition of the

21 standard oxygen equivalence ratio $(\lambda)$ used. From above, $\lambda$ was defined as the ratio

22 between the supplied $\mathrm{O}_{2}$ and the $\mathrm{O}_{2}$ addition at stoichiometric combustion. All

23 experiments were run at the same oxygen equivalence ratio $(\lambda=0.44)$. As the total

24 amount of oxygen available for reaction with $\mathrm{C}$ and $\mathrm{H}$ is highly influenced by the 
1 oxygen content in the fuel, this variable will surely influence the gasification process

2 chemistry if not compensated for.

3 If we define another variable, the Relative Oxygen Content (ROC), taking into account

4 the whole oxygen content inside the gasifier, we create a fuel independent variable. The

5 ROC was previously defined by Stemmler et al. [26] as:

$6 \quad R O C=\frac{o_{2}^{\text {gasi }}+O_{2}^{\text {feed }}}{O_{2}^{\text {stoic }}}$

7 where the superscripts are gasification (supplied $\mathrm{O}_{2}$ ), feedstock and stoichiometric,

8 respectively. Here the stoichiometric $\mathrm{O}_{2}$ is defined as the total amount of $\mathrm{O}_{2}$ available at

9 stoichiometric combustion, i.e. both from the oxidant supply and from the feedstock.

10 As seen in Table 1, the oxygen content of the feedstock decreases with the degree of

11 torrefaction. This implies that gasification experiments of the fuels in this work were

12 performed at different ROC, and thus different stoichiometry, in the gasifier. Therefore,

13 when gasifying fuels with different composition of $\mathrm{C}, \mathrm{H}$ and $\mathrm{O}$ in the future, it would be

14 beneficial to operate the gasification process at constant ROC instead of at constant $\lambda$.

15 Gasification of the Torr-340 fuel resulted in significantly lower $\mathrm{CH}_{4}$ concentration, at

16 any specific process temperature, compared to the other fuels in this work. Figure 7, in

17 which the $\mathrm{CH}_{4}$ concentrations are plotted against a common temperature axis illustrates

18 this phenomenon. One possible explanation can be due to the fact that the torrefaction

19 process removes lot of the volatile components of the biomass. The relationship

20 between $\mathrm{CH}_{4}$ release from pyrolysis and the biomass composition is however not clear

21 in the existing literature. E.g. Couhert et al. [27] concluded that it was not possible to

22 predict the pyrolysis gas yields, from an additivity law, from the biomass composition

23 of cellulose, hemicellulose and lignin. Moreover, the pyrolysis yield of $\mathrm{CH}_{4}$ showed no 
1 correlation to the volatiles content of the tested biomasses. Nor showed the studies by

2 Couhert et al. [21], Chen et al. [22] or Qin et al. [28, 29] any relationship between the

3 biomass volatile content and the $\mathrm{CH}_{4}$ yield from gasification. This was regardless

4 whether the volatile content was reduced by torrefaction or by comparing biomasses

5 with different initial volatile contents.

6 Higher flame temperature, in which $\mathrm{CH}_{4}$ decomposes thermally, or longer residence

7 time in the gasifier are other possible explanations to the reduced $\mathrm{CH}_{4}$ yield for the

8 Torr-340 fuel. The cause of this behavior is still unclear and needs to be investigated

9 further.

10 Table 4 presents the gasification performance figures for the temperature range $1210-$

$111250^{\circ} \mathrm{C}$. The two mildest torrefied fuels, Torr-300 and Torr-demo, resulted in the

12 highest carbon conversion and CGE figures; whereas the carbon conversion and CGE

13 were lower for the Raw and Torr-340 fuels. This is in accordance with the results

14 obtained by Chen et al.[22], who found an optimum in CGE at intermediate torrefaction

15 temperature. However, it should be noted that there was a problem with air leakage into

16 the gas sampling system for the Torr-300 experiment, which may have increased

17 experimental error of that experiment. The carbon conversion for the Torr-300

18 experiment was over predicted, probably as an effect of the gas sampling problem.

19 The carbon conversion is dependent on several different factors such as: the fuel particle

20 size distribution, the reactivity of the burning fuel particles, ROC, process temperature

21 and char reactivity. Despite the smallest fuel particle size distribution, the Torr-340 fuel

22 resulted in the lowest carbon conversion. From the experiments in this work it is not

23 possible to state whether it is because of a changed reactivity of the severely torrefied 
1 fuel or if it is an effect of reduced ROC in the gasifier compared to the other

2 experiments.

3 An interesting parameter to study is the plant efficiency, $\eta_{\text {plant }}$, which was significantly

4 affected by the torrefaction pretreatment. The $\eta_{\text {plant }}$ can be interpreted as the ratio

5 between available energy in the cooled syngas and the thermal energy in the

6 corresponding fuel, after taking the power consumption for milling into account. This

7 means that $\eta_{\text {plant }}$ equals $\mathrm{CGE}_{\text {power }}$ if there was no power consumption for milling. The

8 torrefied fuels resulted in $\eta_{\text {plant }}$ approximately $0.01-0.02$ units below the corresponding

$9 \mathrm{CGE}_{\text {power, }}$, whereas the $\eta_{\text {plant }}$ for the Raw fuel was significantly lower ( 0.09 units) than

10 the corresponding $\mathrm{CGE}_{\text {power }}$ due to a high power consumption for milling. However, the

11 yield and efficiency of the torrefaction process itself was not considered in the present

12 reasoning and the cost of torrefied fuels may potentially be higher than dried fuels for

13 large scale applications. Thus, the benefit of low power consumption for milling may be

14 canceled by a higher price of the torrefied fuels.

\section{General conclusions}

- The carbon conversion efficiency from gasification was enhanced by an intermediate torrefaction pretreatment, whereas both less- and more severe torrefaction resulted in reduced carbon conversions.

- The $\mathrm{CH}_{4}$ yield was significantly reduced for the most severely torrefied fuel. The reason behind this behavior needs to be further investigated.

- On a general basis the torrefied fuels were feasible in terms of fuel handling/feeding and operation in the pressurized entrained flow gasification plant. 


\section{Acknowledgement}

8 The authors of this work would like to acknowledge the financial support from,

9 Swedish Energy Agency, the industrial consortium and the academic partners for

10 founding of this work through the Swedish Biomass Gasification Centre and SECTOR a

11 FP7 financed project. We also thank Bio4Energy, a strategic research environment

12 appointed by the Swedish government. Furthermore, all efforts from ETC colleagues

13 and the industrial partner Infjärdens Värme AB in the PEBG project are thankfully

14 acknowledged. 
2 [1] C. Higman and M. van der Burgt. Gasification (2nd ed. ed.) 2008.

[2] (2010). NETL: 2010 World Gasification Database; (Accessed June 17, 2013).

4

[3] R. W. R. Zwart, H. Boerrigter and A. van der Drift. The impact of biomass pretreatment on the feasibility of overseas biomass conversion to fischer-tropsch products. Energy and Fuels 20(5), pp. 2192-2197. 2006.

[4] R. M. Swanson, A. Platon, J. A. Satrio and R. C. Brown. Techno-economic analysis of biomass-to-liquids production based on gasification. Fuel 89(SUPPL. 1), pp. S11S19. 2010.

[5] A. van der Drift, H. Boerrigter, B. Coda, M. K. Cieplik and K. Hemmes, "Entrained flow gasification of biomass," ECN, Petten, Netherlands, Tech. Rep. ECN-C-04-039, 2004.

[6] F. Weiland, H. Hedman, M. Marklund, H. Wiinikka, O. Öhrman and R. Gebart. Pressurized oxygen blown entrained-flow gasification of wood powder. Energy and Fuels 27(2), pp. 932-941. 2013.

[7] F. Weiland, H. Wiinikka, H. Hedman, M. Marklund and R. Gebart, "Pressurized entrained flow gasification of biomass powder - initial results from pilot plant experiments". Proceedings: The 4th nordic wood biorefinery conference, Helsinki, Finland 23-25 october, 2012.

[8] C. Wolters, M. Kanaar and J. H. A. Kiel, "Co-gasification of biomass in the 250 MWe IGCC plant "Willem alexander centrale". presentation at the biomass gasification workshop at the 2nd biomass conference," in Rome, Italy, May 10-14, 2004.

[9] N. Padban, "Experiences from large-scale test with torrefied biomass fuel at the IGCC plant willem alexander centrale". The 4th central european biomass conference in Graz, Austria (January 15-18, 2014), 2014.

[10] E. Henrich and F. Weirich. Pressurized entrained flow gasifiers for biomass. Environ. Eng. Sci. 21(1), pp. 53-64. 2004.

[11] A. Joppich and H. Salman. Wood powder feeding, difficulties and solutions. Biomass Bioenergy 16(3), pp. 191-198. 1999.

[12] B. Coda, M. K. Cieplik, P. J. de Wild and J. H. A. Kiel. Slagging behavior of wood ash under entrained-flow gasification conditions. Energy and Fuels 21(6), pp. 36443652. 2007.

[13] A. Nordin, L. Pommer, M. Nordwaeger and I. Olofsson, "Biomass conversion through torrefaction," in Technologies for Converting Biomass to Useful EnergyAnonymous CRC Press ISBN 9780415620888, 2013. 
[14] A. Uslu, A. P. C. Faaij and P. C. A. Bergman. Pre-treatment technologies, and their effect on international bioenergy supply chain logistics. techno-economic evaluation of torrefaction, fast pyrolysis and pelletisation. Energy 33(8), pp. 1206-1223. 2008.

[15] M. Svanberg and Á Halldórsson. Supply chain configuration for biomass-toenergy: The case of torrefaction. International Journal of Energy Sector Management 7(1), pp. 65-83. 2013.

[16] A. I. P. Magalhães, D. Petrovic, A. L. Rodriguez, Z. A. Putra and G. Thielemans.

8 Techno-economic assessment of biomass pre-conversion processes as a part of biomass-

9 to-liquids line-up. Biofuels, Bioproducts and Biorefining 3(6), pp. 584-600. 2009.

[17] K. Svoboda, M. Pohořelý, M. Hartman and J. Martinec, "Pretreatment and feeding pp. 629-635, 2009.

[18] J. C. Meerman, A. Ramírez, W. C. Turkenburg and A. P. C. Faaij. Performance of simulated flexible integrated gasification polygeneration facilities. part A: A technicalenergetic assessment. Renewable and Sustainable Energy Reviews 15(6), pp. 25632587. 2011.

[19] J. C. Meerman, A. Ramírez, W. C. Turkenburg and A. P. C. Faaij. Performance of simulated flexible integrated gasification polygeneration facilities, part B: Economic evaluation. Renewable and Sustainable Energy Reviews 16(8), pp. 6083-6102. 2012.

[20] J. C. Meerman, M. M. J. Knoope, A. Ramírez, W. C. Turkenburg and A. P. C. Faaij. Technical and economic prospects of coal- and biomass-fired integrated gasification facilities equipped with CCS over time. International Journal of Greenhouse Gas Control 16pp. 311-323. 2013.

[21] C. Couhert, S. Salvador and J. -. Commandré. Impact of torrefaction on syngas production from wood. Fuel 88(11), pp. 2286-2290. 2009.

[22] Q. Chen, J. S. Zhou, B. J. Liu, Q. F. Mei and Z. Y. Luo. Influence of torrefaction pretreatment on biomass gasification technology. Chinese Science Bulletin 56(14), pp. 1449-1456. 2011.

[23] N. J. Russell. Gelification of victorian tertiary soft brown coal wood. I. relationship between chemical composition and microscopic appearance and variation in the degree of gelification. International Journal of Coal Geology 4(2), pp. 99-118. 1984. DOI: 10.1016/0166-5162(84)90010-7.

[24] H. Kassman, J. Pettersson, B. Steenari and L. Åmand. Two strategies to reduce gaseous $\mathrm{KCl}$ and chlorine in deposits during biomass combustion - injection of ammonium sulphate and co-combustion with peat. Fuel Process Technol 105(0), pp. 170-180. 2013. . DOI: 10.1016/j.fuproc.2011.06.025.

[25] K. O. Gard. Biomass based small scale combined heat and power technologies. Unpublished Lulea University of Technology, Department of Applies Physics and Mechanical Engineering 2008. 
1 [26] M. Stemmler and M. Müller. Theoretical evaluation of feedstock gasification using $2 \mathrm{H} 2 / \mathrm{C}$ ratio and $\mathrm{ROC}$ as main input variables. Industrial and Engineering Chemistry

3 Research 49(19), pp. 9230-9237. 2010.

4 [27] C. Couhert, J. -. Commandre and S. Salvador. Is it possible to predict gas yields of 5 any biomass after rapid pyrolysis at high temperature from its composition in cellulose, 6 hemicellulose and lignin? Fuel 88(3), pp. 408-417. 2009.

7 [28] K. Qin, P. A. Jensen, W. Lin and A. D. Jensen. Biomass gasification behavior in an 8 entrained flow reactor: Gas product distribution and soot formation. Energy and Fuels 9 26(9), pp. 5992-6002. 2012.

10 [29] K. Qin, W. Lin, P. A. Jensen and A. D. Jensen. High-temperature entrained flow 11 gasification of biomass. Fuel 93pp. 589-600. 2012. 


\section{Figure captions}

2 Figure 1 Schematic process flow diagram for the PEBG process.

3 Figure 2 Pictures taken from a Zeiss light microscope. The fuel materials were all

4 milled using a sieve size of $0.75 \mathrm{~mm}$ in the hammer mill and these pictures show

5 representative samples of the resulting powders after milling. The powders are Raw (A),

6 Torr-300 (B), Torr-340 (C) and Torr-demo (D).

7 Figure 3 Process temperature profile (top pane) and main gas (dry, $\mathrm{N}_{2}$ free) composition

8 (bottom pane) for the Raw fuel material.

9 Figure 4 Process temperature profile (top pane) and main gas (dry, $\mathrm{N}_{2}$ free) composition

10 (bottom pane) for the Torr-300 fuel material.

11 Figure 5 Process temperature profile (top pane) and main gas (dry, $\mathrm{N}_{2}$ free) composition

12 (bottom pane) for the Torr-340 fuel material.

13 Figure 6 Process temperature profile (top pane) and main gas (dry, $\mathrm{N}_{2}$ free) composition

14 (bottom pane) for the Torr-demo fuel material.

15 Figure 7 Measured $\mathrm{CH}_{4}$ concentration in the syngas (dry and $\mathrm{N}_{2}$ free) as a function of

16 measured process temperature (average middle reactor temperatures). 


\section{Tables}

2 Table 1. Chemical composition of raw and torrefied fuels.

\section{Gasification feeds}

Composition Unit $\quad$ Raw $^{\mathrm{a}} \quad$ Torr-300 $\quad$ Torr-340 Torr-demo

\begin{tabular}{lccccc}
\hline Birch & $\%$ & 45 & 45 & 45 & 0 \\
Pine & $\%$ & 55 & 35 & 35 & 50 \\
Spruce & $\%$ & 0 & 20 & 20 & 50 \\
\hline
\end{tabular}

\section{Torrefaction settings}

\begin{tabular}{lccccc}
\hline Time & $\min$ & -- & 4.5 & 4.5 & $45-60$ \\
Temperature & ${ }^{\circ} \mathrm{C}$ & -- & 300 & 340 & 245 \\
\hline
\end{tabular}

\section{Torrefaction results}

\begin{tabular}{llllll}
\hline$\eta_{\text {m,daf }}$ & $\%$ & 100 & 80.2 & 49.2 & $\sim 78^{\mathrm{b}}$ \\
$\eta_{\mathrm{E}, \mathrm{HHV}, \text { daf }}$ & $\%$ & 100 & 86.3 & 65.1 & 80.5 \\
\hline
\end{tabular}

Fuel analysis

\begin{tabular}{|c|c|c|c|c|c|}
\hline Moisture content $^{\mathrm{c}}$ & $\%$ & 3.0 & 2.4 & 3.1 & 2.2 \\
\hline LHV & $\mathrm{MJ} / \mathrm{kg}_{\mathrm{DS}}$ & 19.15 & 20.57 & 25.06 & 20.09 \\
\hline $\mathrm{HHV}_{\mathrm{daf}}$ & $\mathrm{MJ} / \mathrm{kg}_{\text {daf }}$ & 20.69 & 22.02 & 26.53 & 21.49 \\
\hline Ash & $\%_{\text {mass,DS }}$ & 0.9 & 0.7 & 1.2 & 0.5 \\
\hline Volatiles & $\%_{\text {mass,DS }}$ & 82.5 & 78.3 & 56.8 & 76.7 \\
\hline Fixed carbon & $\%_{\text {mass,DS }}$ & 16.6 & 21.0 & 42.0 & 22.8 \\
\hline $\mathrm{C}$ & $\% 0_{\text {mass,DS }}$ & 50.9 & 54.4 & 65.4 & 53.1 \\
\hline $\mathrm{H}$ & $\%_{\text {mass,DS }}$ & 6.2 & 6.0 & 5.3 & 5.9 \\
\hline $\mathrm{N}$ & $\%_{\text {mass,DS }}$ & 0.2 & 0.2 & 0.3 & 0.1 \\
\hline $\mathrm{O}$ & $\%_{\text {mass,DS }}$ & 41.8 & 38.7 & 27.8 & 40.4 \\
\hline S & $\% 0_{\text {mass,DS }}$ & 0.02 & $<0.01$ & $<0.01$ & $<0.01$ \\
\hline $\mathrm{Cl}$ & $\%_{\text {mass,DS }}$ & $<0.01$ & $<0.01$ & $<0.01$ & $<0.02$ \\
\hline
\end{tabular}

3 a Similar, but not exactly the same as the original biomass for the Torr-300 and Torr-

4340 fuels.

$5{ }^{\mathrm{b}}$ Approximated value

$6 \quad{ }^{\mathrm{c}}$ Moisture content of feed prior to gasification (pulverized fuels)

7 
Table 2 Gasification settings

\begin{tabular}{|c|c|c|c|c|c|}
\hline Parameter & Unit & Raw & Torr-300 & Torr-340 & Torr-demo \\
\hline Fuel feeding rate & $\mathrm{kg} / \mathrm{h}$ & 55 & 50 & 40 & 50 \\
\hline Thermal power & $\mathrm{kW}_{\text {th }}$ & 284 & 265 & 258 & 271 \\
\hline $\mathrm{O}_{2}$ flow rate & $\mathrm{kg} / \mathrm{h}$ & 34 & 34 & 33 & 32 \\
\hline $\mathrm{N}_{2}$ flow rate & $\mathrm{kg} / \mathrm{h}$ & 11 & 11 & 10 & 10 \\
\hline $\begin{array}{l}\text { Oxygen equivalence } \\
\text { ratio }(\lambda)\end{array}$ & - & 0.44 & 0.44 & 0.44 & 0.44 \\
\hline $\begin{array}{l}\text { Relative Oxygen } \\
\text { Content (ROC) }\end{array}$ & - & 0.58 & 0.56 & 0.52 & 0.57 \\
\hline System pressure & bar(a) & 2.0 & 2.0 & 2.0 & 2.0 \\
\hline Quench water level $^{\mathrm{d}}$ & $\%$ & 30 & 33 & 33 & 30 \\
\hline
\end{tabular}

$2{ }^{\mathrm{d}}$ Bubbling quench if the water level $>20 \%$. 
1 Table 3 Milling energy consumption and resulting fuel powder bulk density for the considered fuel materials.

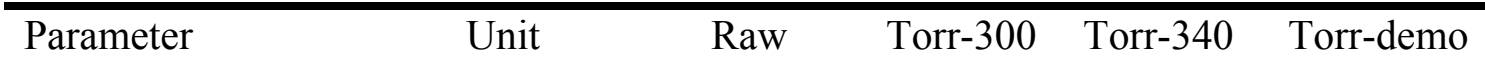

$\begin{array}{lllll}\text { Milling energy } \quad \mathrm{kWh}_{\mathrm{el}} / \mathrm{MWh}_{\mathrm{th}} & 35.9 \pm 0.7 & 8.1 \pm 2.0 & 6.1 \pm 0.7 & 4.6 \pm 0.3\end{array}$

Fuel powder bulk

$\mathrm{kg} / \mathrm{m}^{3} \quad 279 \quad 213 \quad 262 \quad 486$

density

2 
1 Table 4 Gasification results measured within process temperature range $1210-1250^{\circ} \mathrm{C}$. Gas compositions as average dry and $\mathrm{N}_{2}$ free.

\begin{tabular}{|c|c|c|c|c|c|}
\hline & Unit & Raw & Torr-300 & Torr-340 & Torr-demo \\
\hline $\mathrm{CO}$ & $\mathrm{mol} \%$ & 50.0 & 54.6 & 60.3 & 54.0 \\
\hline $\mathrm{H}_{2}$ & $\mathrm{~mol} \%$ & 26.2 & 27.2 & 26.7 & 28.0 \\
\hline $\mathrm{CO}_{2}$ & $\mathrm{~mol} \%$ & 23.3 & 18.6 & 12.7 & 16.9 \\
\hline $\mathrm{CH}_{4}$ & $\mathrm{~mol} \%$ & 1.8 & 1.6 & 0.9 & 1.8 \\
\hline $\mathrm{H}_{2} / \mathrm{CO}$ & - & 0.52 & 0.50 & 0.44 & 0.52 \\
\hline Carbon conversion & - & 0.89 & 1.10 & 0.84 & 0.97 \\
\hline $\mathrm{LHV}_{\text {power }}$ & $\mathrm{MJ} / \mathrm{kg}^{\mathrm{e}}$ & 7.2 & 8.1 & 8.3 & 8.3 \\
\hline $\mathrm{LHV}_{\text {fuel }}$ & $\mathrm{MJ} / \mathrm{kg}^{\mathrm{e}}$ & 6.6 & 7.6 & 8.0 & 7.7 \\
\hline $\mathrm{CGE}_{\text {power }}$ & - & 0.58 & 0.81 & 0.63 & 0.70 \\
\hline $\mathrm{CGE}_{\text {fuel }}$ & - & 0.54 & 0.76 & 0.61 & 0.65 \\
\hline Plant efficiency, $\eta_{\text {plant }}$ & - & 0.49 & 0.79 & 0.62 & 0.69 \\
\hline
\end{tabular}




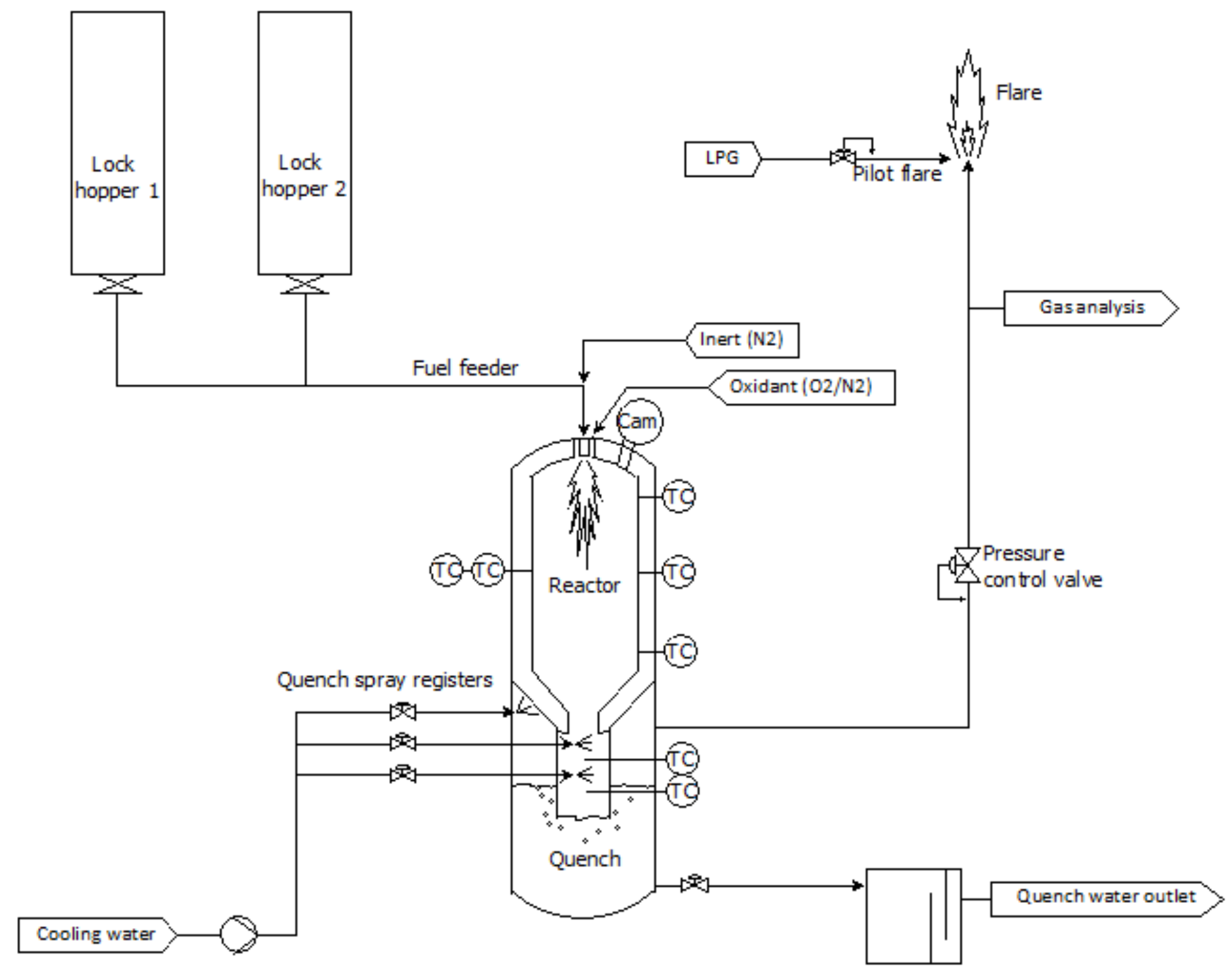



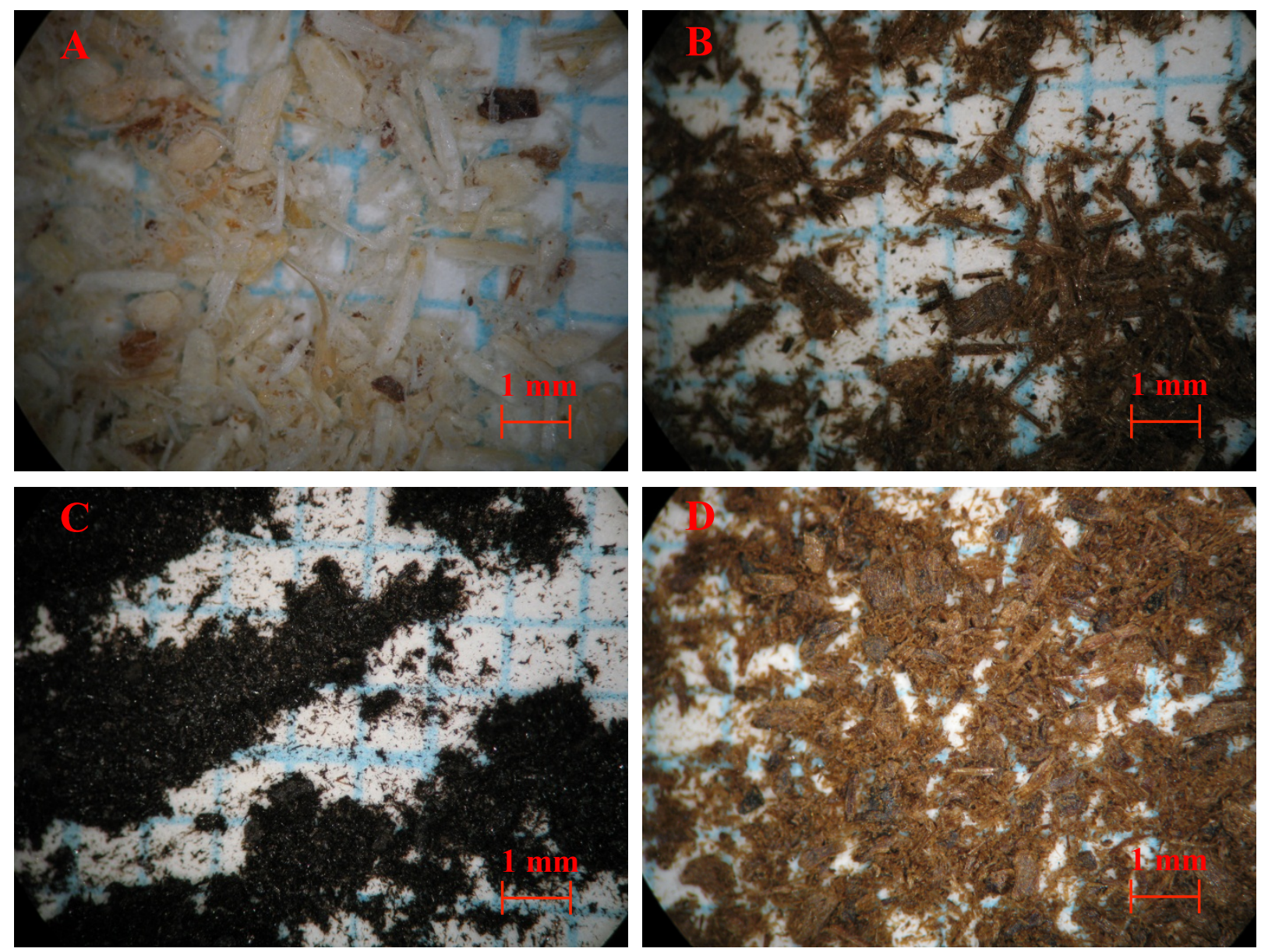

Figure 2 

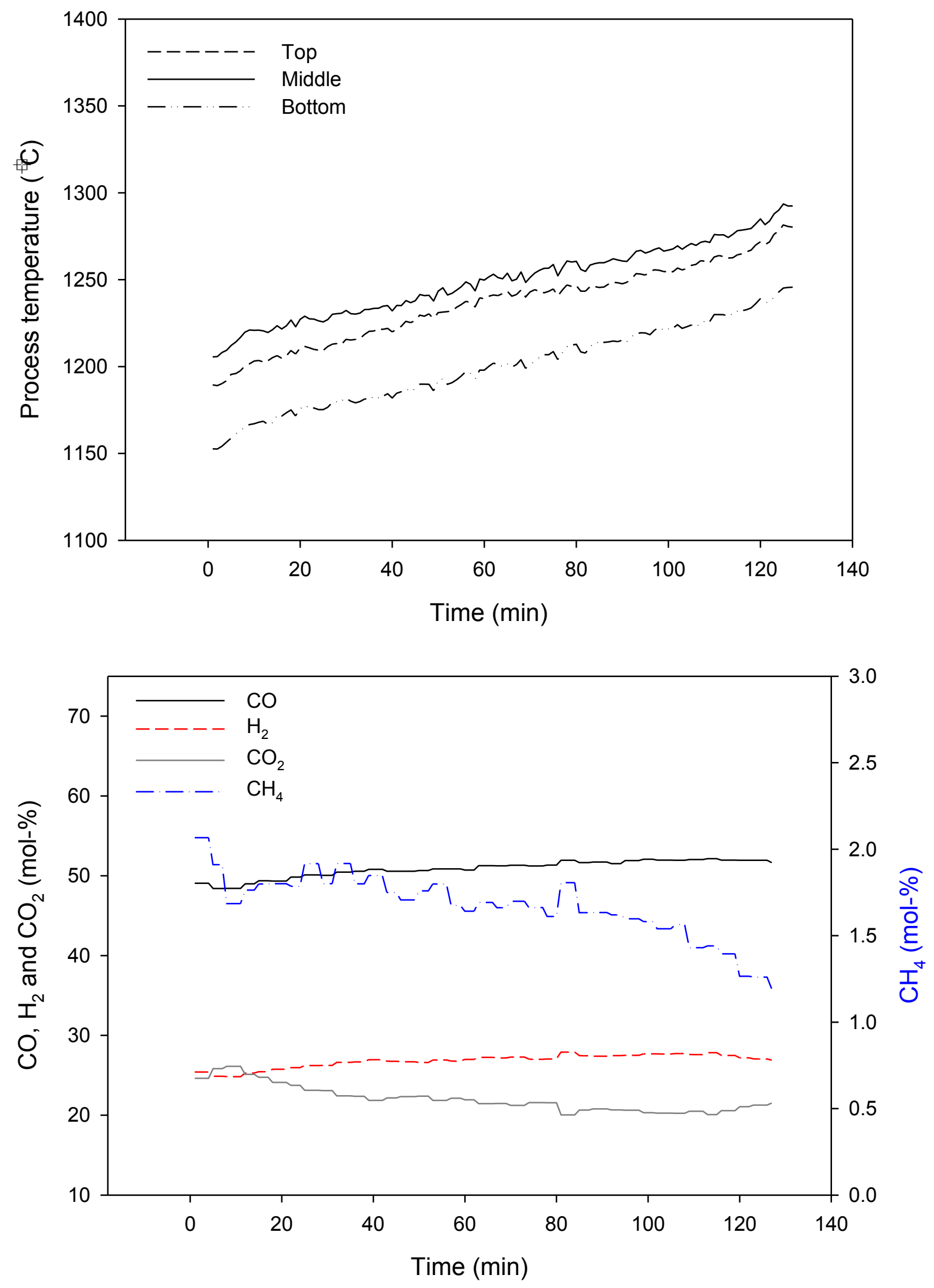

Figure 3 

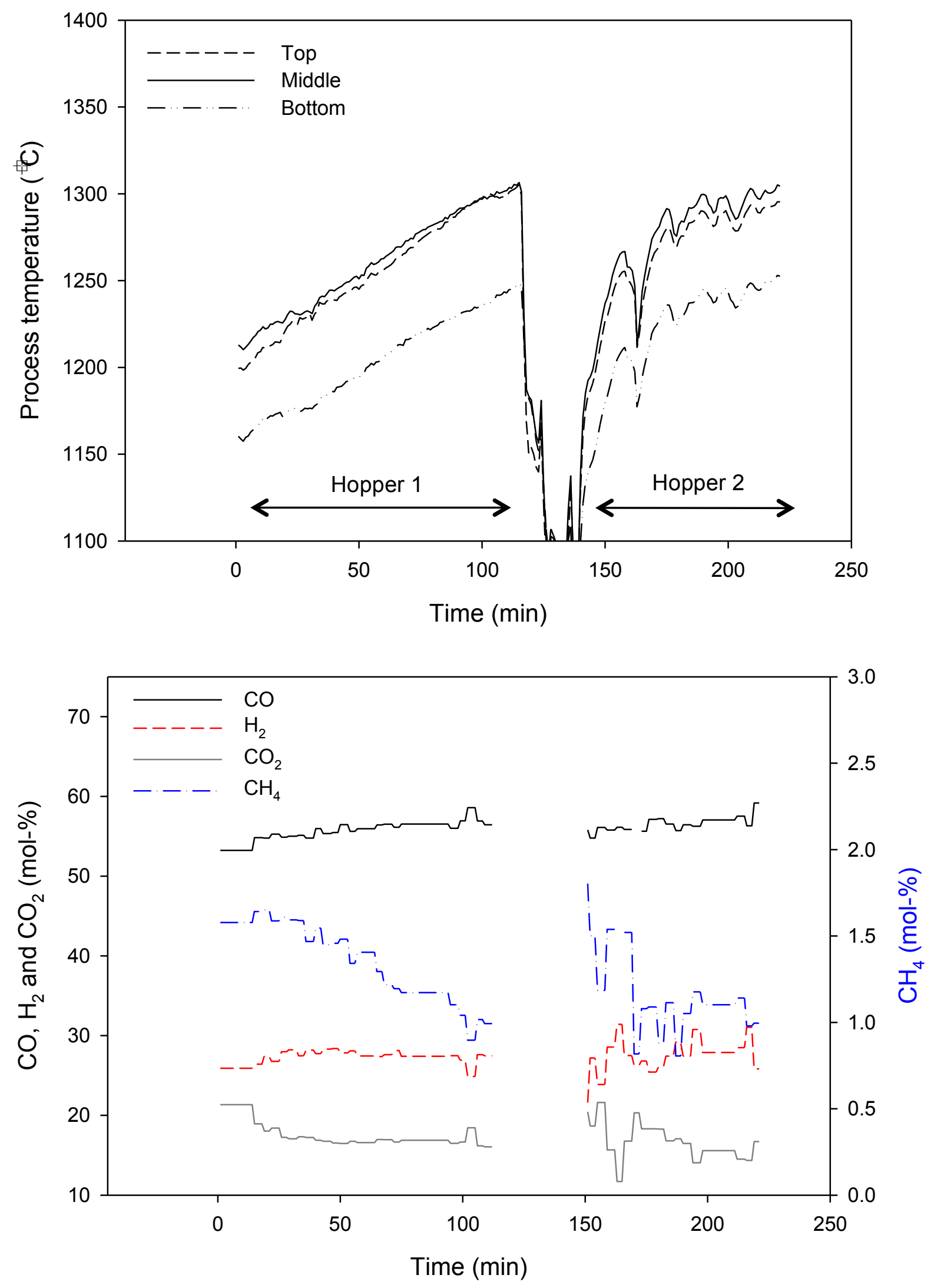

Figure 4 

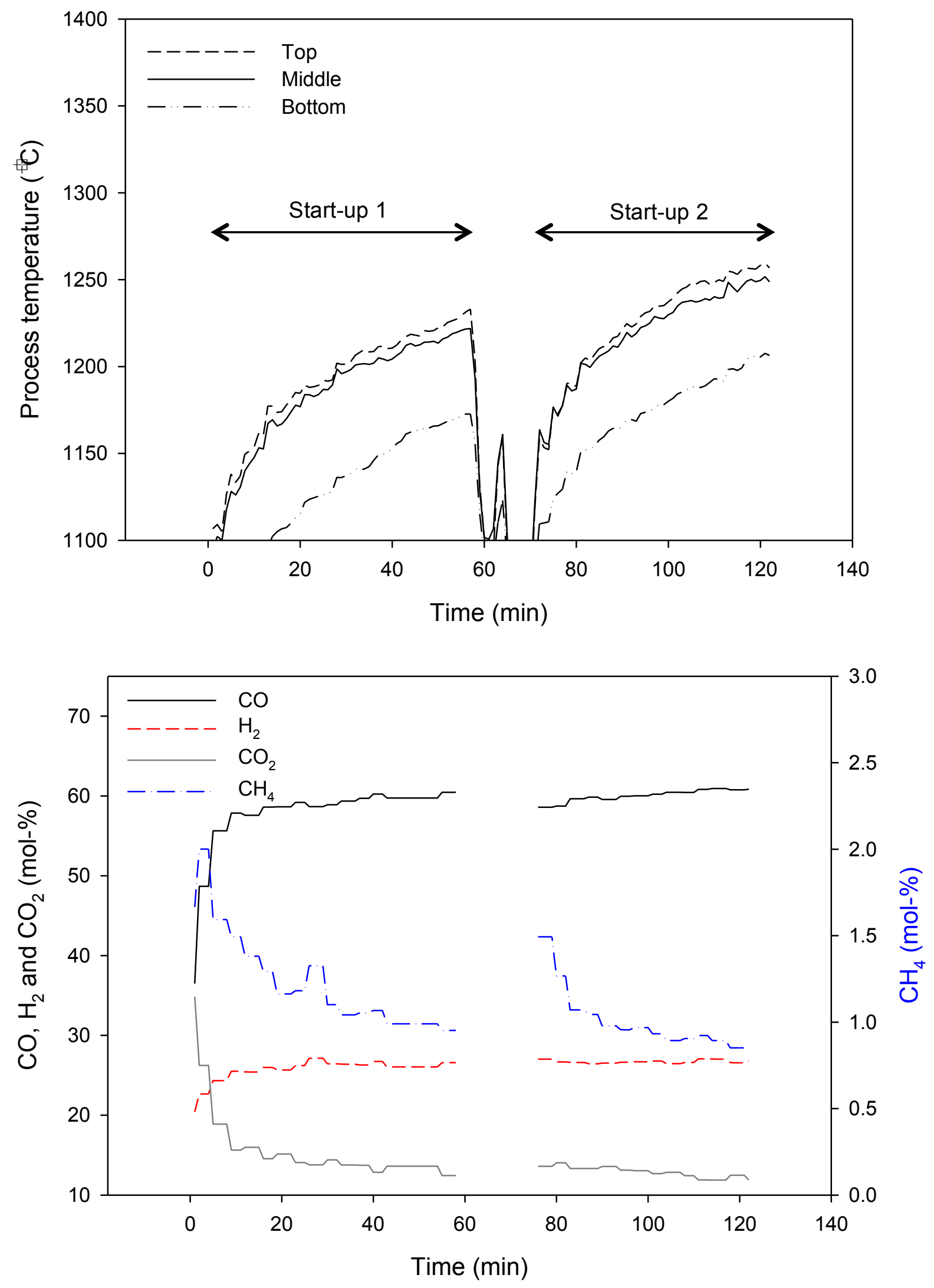

Figure 5 

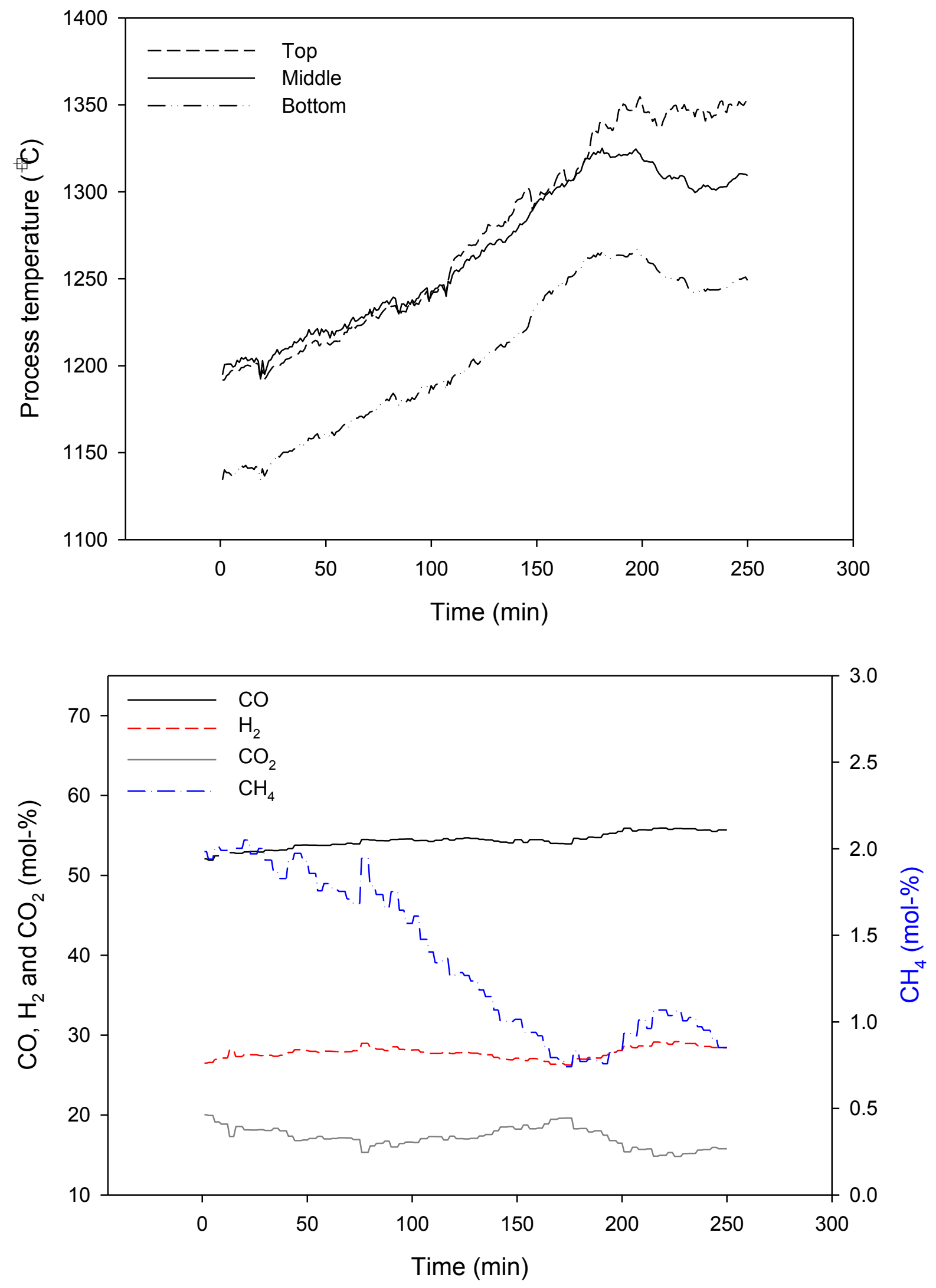

Figure 6 


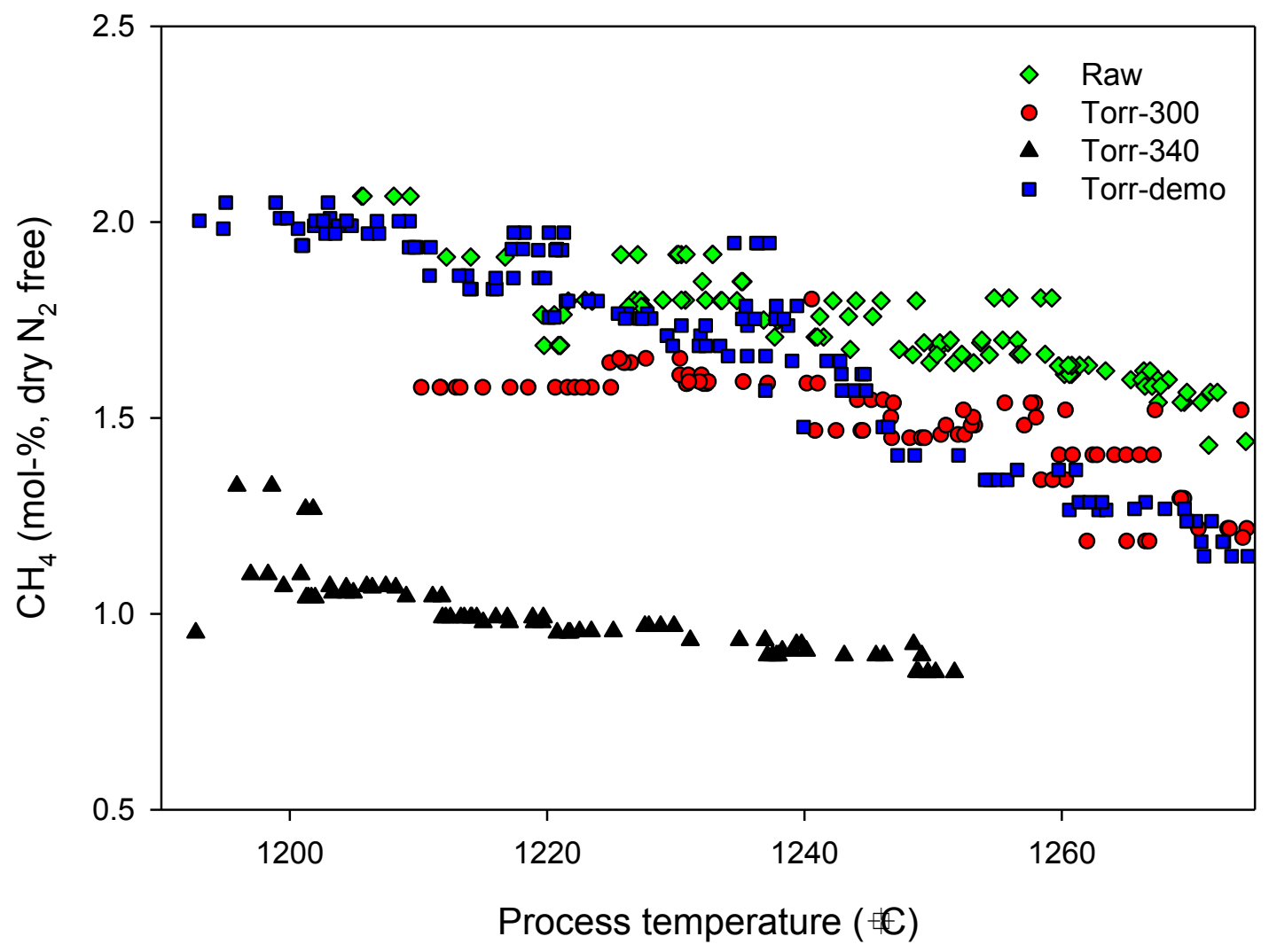

Figure 7 